\title{
Decadal changes in land degradation status of India
}

\author{
K. Sreenivas ${ }^{1, *}$, G. Sujatha ${ }^{1}$, Tarik Mitran ${ }^{1}$, K. G. Janaki Rama Suresh ${ }^{1}$, \\ T. Ravisankar ${ }^{2}$ and P. V. N. Rao $^{3}$ \\ ${ }^{1}$ Soil and Land Resources Assessment Division, \\ ${ }^{2}$ Land Resources Use Mapping and Monitoring Group, \\ ${ }^{3}$ Remote Sensing Applications Area, National Remote Sensing Centre, ISRO, Balanagar, Hyderabad 500 037, India
}

\begin{abstract}
Robust data on the spatial distribution of land degradation is important for resource conservation planning. Spatial land degradation status of India was mapped using multi-temporal Linear Imaging Self Scanning Sensor (LISS-III) data acquired from Resourcesat-1/2 during 2005-2006 and 2015-2016 under the Natural Resources Census programme of the Indian Space Research Organisation. Heads-up on-screen visual interpretation of multi-season satellite data was carried out, supported by digital elevation model and other historical maps available. Visual interpretation cues were developed and employed across various partner institutions to achieve consistency in mapping. The outputs were subjected to two-stage quality check. Results indicate that the total land degradation of India was $91.2 \mathrm{M}$ ha $(27.77 \%$ of the geographical extent of the country) during 2015-2016 against $91.3 \mathrm{M}$ ha during 2005-2006. During the ten-year period, there was an overall decrease of around $0.1 \mathrm{M}$ ha in degraded land. However, noticeable intra- and inter-class changes were observed in land degradation during the ten-year period. Major reclamation was noticed in sand dunes which were converted into crop lands by levelling them. Substantial decrease in severity and extent of salt-affected soils was noticed in Uttar Pradesh.
\end{abstract}

Keywords: Change detection, land degradation, visual interpretation, sand dunes, soil erosion, spatial distribution.

LAND degradation (LD) is a temporary or permanent impairment of productivity of land through deterioration of physical, chemical or biological aspects. India is bestowed with vast natural resources. However, it suffers from a variety of LD problems affecting the quality and quantity of available land. India homes more than $18 \%$ of world's population over an area that is just $2.42 \%$ of global spread $^{1}$. At present per capita arable land is around 0.15 ha in India and it is expected to decrease to a meagre 0.09 ha by 2075 (ref. 2). Ensuring sustainable land management is important, with India having an estimated $28 \%$ of its geographical area under $\mathrm{LD}^{3}$. Development or

*For correspondence. (e-mail: sreenivas_k@nrsc.gov.in) reclamation of these degraded lands is an important option available to increase food production in the country, to meet the requirements of the growing population as well as restoring fragile ecosystems. The lack of proper land-use planning and adequate information on soil resources has resulted in many of the present-day LD problems in India. These are mainly severe erosion in catchments leading to siltation of reservoirs, salinity/alkalinity and waterlogging in command areas, etc. ${ }^{4}$.

LD neutrality is gaining importance to compensate for the natural resources requirement of the ever increasing population. During the recent Conference of Parties (COP-14), India has committed to United Nations Convention to Combat Desertification (UNCCD) to achieve LD neutrality by 2030 (https://www.unccd.int). The country is the torchbearer for development of watersheds, in which information on LD status becomes an important component for prioritization. All these efforts need to be supported with thorough technical inputs, effective policies, adequate financial resources, participation of stakeholders, and a strong institutional mechanism to execute and monitor the efforts.

Remote sensing data are being regularly employed in the survey of degraded soils, because of the development of operational methodologies 5 . Several attempts have been made by various organizations to map/derive the spatial distribution of LD status in India. Table 1 summarizes some of these efforts.

To assess and monitor the status of LD in India, a nationwide LD mapping at $1: 50,000$ scale using multitemporal Resourcesat-1/2 LISS-III data was taken up by the Indian Space Research Organisation (ISRO). This mapping had been carried out using satellite data of 2005-2006 as well as 2015-2016 with due support from partner institutions like State Remote Sensing Centres, Central Arid Zone Research Institute (CAZRI), Jodhpur, Rajasthan, academia and other ISRO Centres with the objectives to monitor LD status at $1: 50,000$ scale using Resourcesat LISS-III satellite data for three seasons ( $k h a-$ rif, rabi and zaid). The exercise will help in finding changes in LD status between 2005-2006 and 2015-2016. The present study highlights the results obtained on decadal changes as well as the current status of LD in India. 
Table 1. National estimates of land degradation (LD) in India

\begin{tabular}{|c|c|c|c|}
\hline Organization & Year & $\begin{array}{l}\text { Area mapped as land } \\
\text { degradation ( } \mathrm{M} \text { ha) }\end{array}$ & Broad methodology \\
\hline $\begin{array}{l}\text { National Remote Sensing Centre (NRSC)/(ISRO) } \\
\quad \text { (present study) })^{14}\end{array}$ & $2015-16$ & 91.20 & Visual interpretation of multi-season LISS-III data \\
\hline Space Applications Centre (SAC)/ISRO & $2011-13$ & 96.40 & Visual interpretation of multi-season $\mathrm{AWiFS}$ data \\
\hline $\mathrm{NRSC}^{\mathrm{ISRO}} \mathrm{I}^{3}$ & $2005-06$ & 91.29 & Visual interpretation of multi-season LISS-III data \\
\hline SAC/ISRO & $2003-05$ & 94.53 & Visual interpretation of multi-season $\mathrm{AWiFS}$ data \\
\hline Department of Land Resources & 2005 & 55.27 & $\begin{array}{l}\text { Visual interpretation of satellite data at } 1: 50,000 \\
\text { scale }\end{array}$ \\
\hline $\begin{array}{l}\text { National Bureau of Soil Survey (NBSS) \& Land } \\
\text { Use Planning (LUP) (revised) })^{15}\end{array}$ & 2005 & 146.82 & Based on $1: 1$ million scale soil map \\
\hline Department of Land Resources & 2000 & 63.8 & $\begin{array}{l}\text { Visual interpretation of satellite data at } 1: 50,000 \\
\text { scale }\end{array}$ \\
\hline NBSS and LUP ${ }^{16}$ & 1994 & 187.7 & $\begin{array}{l}\text { Mapping on } 1: 4 \text { million scale based on the Global } \\
\text { Assessment of Soil Degradation (GLASOD) } \\
\text { guidelines }\end{array}$ \\
\hline $\begin{array}{l}\text { Ministry of Agriculture (MoA), Government of India } \\
(\mathrm{GoI})^{17}\end{array}$ & 1994 & 107.4 & $\begin{array}{l}\text { Elimination of duplication of area. The area } \\
\text { reclaimed also counted }\end{array}$ \\
\hline National Remote Sensing Agency ${ }^{18}$ & 2000 & 53.3 & $\begin{array}{l}\text { Mapping on } 1: 1 \text { million scale based on remote } \\
\text { sensing techniques }\end{array}$ \\
\hline National Wasteland Development Board ${ }^{19}$ & 1985 & 123 & - \\
\hline Society for Promotion of Wastelands Development ${ }^{20}$ & 1984 & 129.58 & Based on secondary estimates \\
\hline Department of Environment ${ }^{7}$ & 1980 & 95.0 & - \\
\hline MoA-Soil and Water Conservation Division ${ }^{21}$ & 1978 & 175 & $\begin{array}{c}\text { Based on the National Commission on Agriculture's } \\
\text { estimates. No systematic survey was undertaken }\end{array}$ \\
\hline National Commission on Agriculture ${ }^{22}$ & 1976 & 148.0 & Based on the secondary data \\
\hline
\end{tabular}

\section{Materials and methods}

\section{Study area and database}

LD status was mapped for the whole land mass of India. For this, the Resouresat-1/2 LISS-III data acquired during August to October (kharif), November to March (rabi) and April to May (summer) of 2005-2006 and 2015-2016 were used. About 900 LISS-III images per season and per year were used in the study. Besides, the salt-affected soil maps prepared during 1985-1990, land-use/land-cover maps prepared at $1: 50,000$ scale as well as wasteland maps generated by the National Remote Sensing Centre (NRSC; http://bhuvan.nrsc.gov.in) were used as reference. Digital elevation model (DEM) employing Cartosat-1 data was used to derive slope information.

\section{Methodology}

The overall approach is based on visual interpretation of ortho-rectified multi-temporal LISS-III satellite data. Initially, a national workshop was conducted in 2005 to achieve consensus on the classification system to be adopted for LD mapping, with the active participation of various State Remote Sensing Centres, Indian Council of Agricultural Research (ICAR) organizations, Agriculture Universities and others. These discussions culminated in the identification of eight major LD processes for mapping, namely water erosion, wind erosion, waterlogging, acidification, salinization/alkalization, anthropogenic, glacial and others with 36 LD classes. Table 2 presents the detailed classification scheme along with class definitions.

Initially, the multi-temporal satellite data of three seasons were ortho-rectified and provided to the partner organizations. To achieve consistency of mapping across various partner institutions, interpretation cues for mapping LD using multi-temporal LISS-III data were developed during the first cycle of LD mapping (2005-2006). The process includes ortho-rectification and radiometric normalization of multi-temporal satellite data, which were used subsequently for preliminary visual interpretation of multi-temporal LISS-III data. Based on the consistency/variation of $\mathrm{LD}$ across terrains with respect to slope, elevation, historical information of salt-affected soils as well as wastelands, field sampling sites were selected. Soil samples were collected from 0 to 15 and 15 to $30 \mathrm{~cm}$ depths wherever salinity/alkalinity or acidification processes were active. About 2913 soil samples collected from across India exclusively under this project were analysed and results used in the categorization of classes under salinization/alkalization as well as acidification processes. Soil chemical analysis was carried out for $\mathrm{pH}$ and electrical conductivity (EC; $1: 2$ soil water suspensions) for identification of nature and degree of the LD problem.

Quality checks at various stages were made as an integral part of the study. These were conducted at data 
RESEARCH ARTICLES

Table 2. Definition of LD classes

Class

Water erosion: sheet erosion - slight

Water erosion: sheet erosion - moderate

Water erosion: sheet erosion - severe

Water erosion: rills

Water erosion: gullies

Water erosion: ravines - shallow

Water erosion: ravines - moderately deep to deep

Wind erosion: sheet - slight

Wind erosion: sheet - moderate

Wind erosion: sheet - severe

Wind erosion: stabilized dunes

Wind erosion: partially stabilized dunes

Wind erosion: unstabilized dunes

Waterlogging: surface ponding - seasonal

Waterlogging: surface ponding - permanent

Waterlogging: subsurface

Salt-affected: saline - slight

Salt-affected: saline - moderate

Salt-affected: saline - severe

Salt-affected: sodic - slight

Salt-affected: sodic - moderate

Salt-affected: sodic - severe

Salt-affected: saline sodic - slight

Salt-affected: saline sodic - moderate

Salt-affected: saline sodic - severe

Rann

Acidity - moderate

Acidity - severe

Frost heaving

Frost shattering

Industrial effluent-affected areas

Mining and dump areas

Brick kiln areas

Mass movement/mass wastage

Barren rocky/stony waste

Miscellaneous - riverine sands/sea ingress areas

Normal
Description

A decrease in depth of the topsoil layer (A horizon) due to more or less uniform removal of soil material by run-off water resulting in soil loss of 10-20 tonnes/ha/yr

A decrease in depth of the topsoil layer (A horizon) due to more or less uniform removal of soil material by run-off water resulting in soil loss of 20-40 tonnes/ha/yr

A decrease in depth of the topsoil layer (A horizon) due to more or less uniform removal of soil material by run-off water resulting in soil loss of more than 40 tonnes/ha/yr

An irregular displacement of soil material causing clearly visible scars in the terrain moderate

Gullies - network of rills - severe

Ravines - shallow - very severe

Ravines - moderately deep to deep - extreme

Sheet erosion - slight uniform displacement of topsoil wind action

Sheet erosion - moderate uniform displacement of topsoil wind action

Sheet erosion - severe uniform displacement of topsoil wind action

Stabilized dunes - slight stabilized sand dunes with good cover of sod-forming plants $(>60 \%$ cover $)$

Partially stabilize dunes - moderate. Partly stabilized sand dunes with moderate cover of sod forming plants (30-60\%) subjected to moderate deformation

Deformation with moderate cover of sod-forming plants (30-60\%).

Unstabilized dunes - severe. Sand dunes subjected to severe deformation. They are generally devoid of any vegetation cover

Surface ponding - slight. Waterlogging with 4-6 months of ponding affecting one crop (excluding paddy)

Surface ponding - moderate. Permanent waterlogging with more than 6 months ponding affecting one crop (excluding paddy areas)

Subsurface water logging. Area with water table close to the surface affecting crop growth and performance. Areas with water table $<2 \mathrm{~m}$ are considered.

$\mathrm{pH}<8.5$ and electrical conductivity (EC) of $2-4 \mathrm{dS} / \mathrm{m}$ for black soil and $4-8 \mathrm{dS} / \mathrm{m}$ for other soils ( $1: 2$ soil water suspension)

$\mathrm{pH}<8.5$ and $\mathrm{EC}$ of $4-8 \mathrm{dS} / \mathrm{m}$ for black soil and $8-16 \mathrm{dS} / \mathrm{m}$ for other soils $(1: 2$ soil water suspension)

$\mathrm{pH}<8.5$ and $\mathrm{EC}$ of $>8 \mathrm{dS} / \mathrm{m}$ for black soil and $>16 \mathrm{dS} / \mathrm{m}$ for other soils $(1: 2$ soil water suspension)

$\mathrm{pH}>8.5$ (1:2 soil : water suspension), and exchangeable sodium percentage (ESP) of $5-10 \%$ for black soil and $15-40 \%$ for other soils

$\mathrm{pH}>8.5$ (1: 2 soil : water suspension), and ESP of 10-20\% for black soil and $40-60 \%$ for other soils

$\mathrm{pH}>8.5$ (1: 2 soil : water suspension), and ESP of $>20 \%$ for black soil and $>60 \%$ for other soils

$\mathrm{pH}<8.5$, EC $2-4 \mathrm{dS} / \mathrm{m}$ and ESP of $5-10 \%$ for black soil, and EC of $4-8 \mathrm{dS} / \mathrm{m}$ and ESP of $15-40 \%$ for other soils

$\mathrm{pH}<8.5$, EC $4-8 \mathrm{dS} / \mathrm{m}$ and ESP of $10-20 \%$ for black soil, and EC of $8-16 \mathrm{dS} / \mathrm{m}$ and ESP of $40-60 \%$ for other soils

$\mathrm{pH}<8.5, \mathrm{EC}>8 \mathrm{dS} / \mathrm{m}$ and ESP of $>20 \%$ for black soil, and $\mathrm{EC}$ of $>16 \mathrm{dS} / \mathrm{m}$ and ESP of $>60 \%$ for other soils

Large contiguous area of salt marshes

Acidity - moderate: $\mathrm{pH} 4.5-5.5(1: 1$ soil- $\mathrm{KCl})$

Forest and paddy areas excluded

Acidity - severe: $\mathrm{pH}<4.5$ (1: 1 soil-KCl)

Forest and paddy areas excluded

Frost heaving. Areas with ice in the subsurface horizons leading to expansion of soil, forming undulations on the surface. This restricts the growth of plants.

Frost shattering. Areas with shuttered material because of freezing and thawing in periglacial environments.

Industrial effluent-affected areas. The areas affected with effluents discharged from industries (areas under industry per se excluded)

Mining. Surface/open-cast mines, including mine dumps

Brick kiln areas

Mass movement/mass wastage: areas with landslides.

Barren rocky/stony waste. Rock outcrops/sheet rock exposures devoid of vegetation

Miscellaneous - riverine sands/sea ingress, etc. Includes mainly sands other than desert areas

No apparent land degradation 


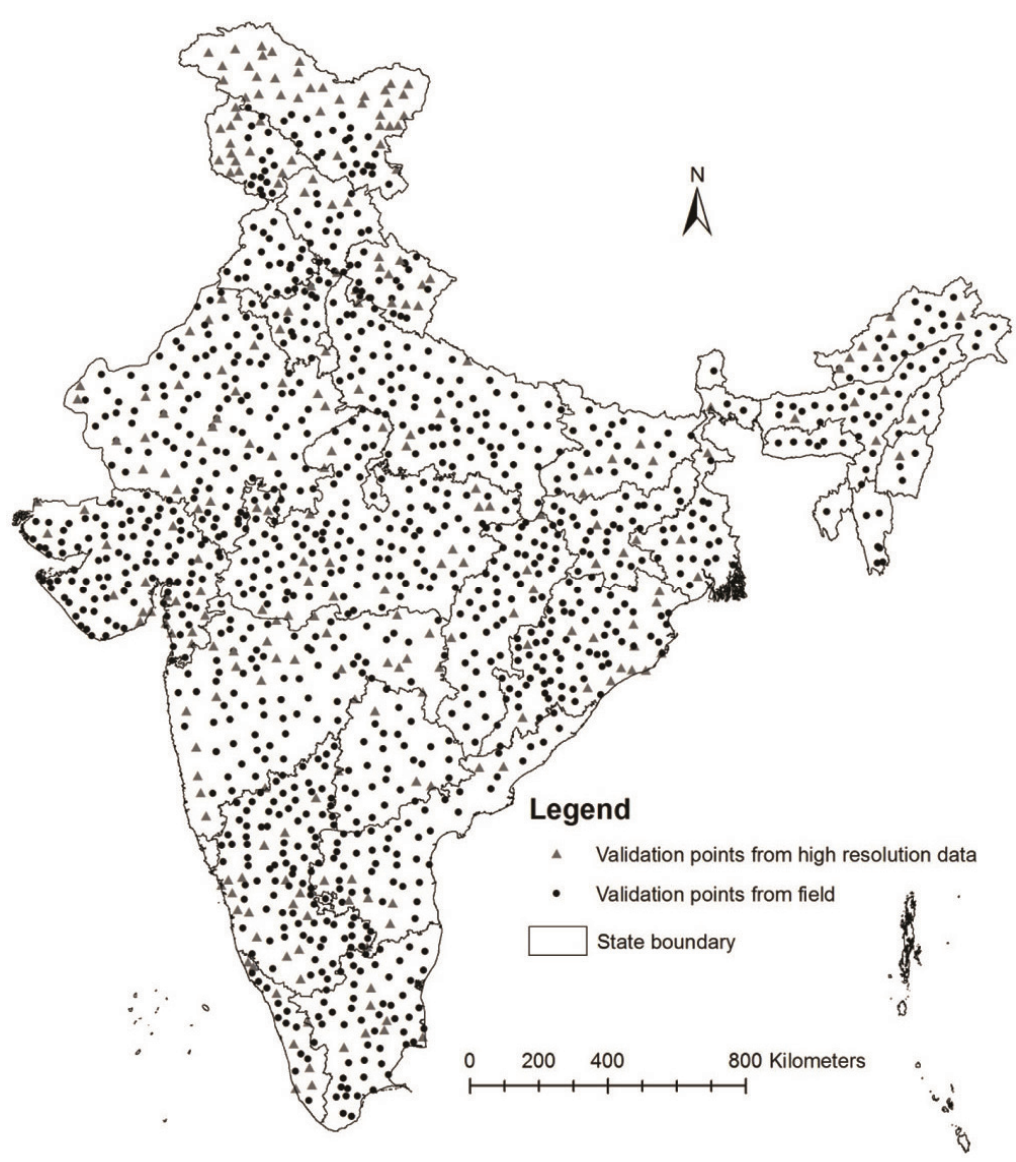

Figure 1. Location of observations used for accuracy assessment.

ingest level, preliminary visual interpretation and final thematic output by the duly constituted inter-centre teams. The quality checks for soil sample analysis were also conducted based on their location vis-à-vis historical maps, temporal variations in reflectance from satellite data, logical range in values and historical soil sample results available with us.

For 2015-2016, changes in area were identified based on visual representation of features in 2005-2006 and 2015-2016 in multi-season LISS-III data and the 20052006 polygons were updated appropriately. A polygon of $3 \mathrm{~mm} \times 3 \mathrm{~mm}$ size (equivalent to 2.25 ha area) and a minimum mapping unit on 1:50,000 scale were retained, except for the significant classes like brick kilns and mass movements, where even smaller than 2.25 ha area was retained. Overlay analysis for LD status of 2005-2006 and 2015-2016 was performed to understand the geospatial variation in $\mathrm{LD}$ changes.

\section{Accuracy assessment}

The accuracy of the LD map was estimated using validation data consisting of 1931 points collected across the country (Figure 1). The contingency matrix was generated using field data as reference points and kappa coefficient of the map estimated for 2015-2016. The error matrix represents cross tabulation of various LD class categories assigned on the map vis-à-vis ground-truth data. The various LD processes classified in the map and reference classes were represented in rows and columns respectively, in the confusion matrix. The kappa coefficient represents the extent of agreement between frequencies of two sets of data collected on two different occasions ${ }^{6}$. The following equation was used to compute the confidence interval of kappa statistic ${ }^{7}$

$$
\mu=z *[p *(1-p) / n]^{1 / 2}
$$

where $\mu$ is the confidence interval, $z$ the function of the level of confidence of the test, $p$ the first-level accuracy of the system/assumed accuracy and $n$ is the number of samples.

\section{Results and discussion}

LD is evidently distributed across various parts of India. The total LD status of the country was estimated at 91.30 $\mathrm{M}$ ha during 2005-2006, while it was 91.21 M ha 


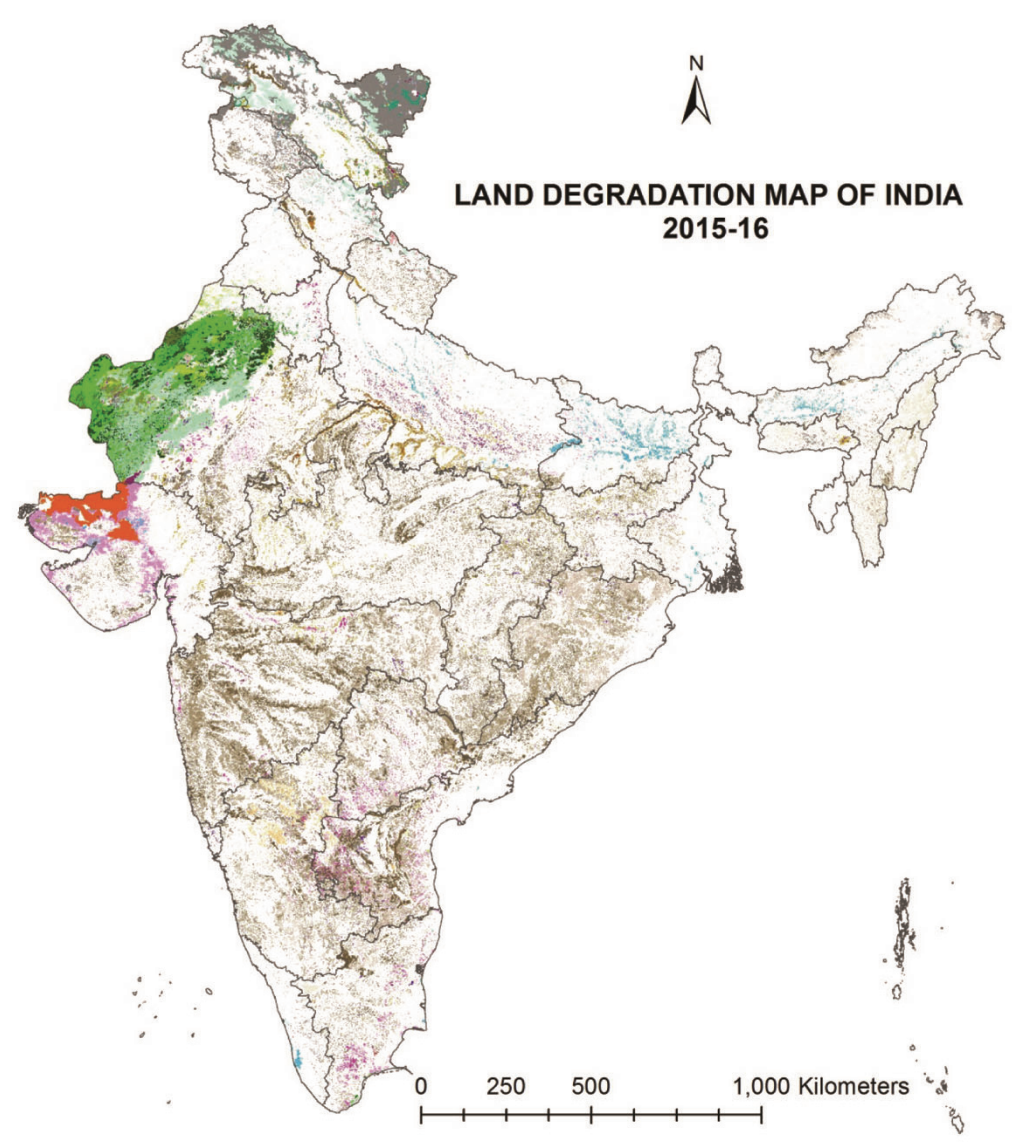

Figure 2. Land degradation map of India 2015-16.

\begin{tabular}{|c|c|c|c|}
\hline Process & Code & Land degradation class & Symbol \\
\hline \multirow[t]{7}{*}{ Water erosion } & A1 & Sheet erosion - slight & \\
\hline & A2 & Sheet erosion - moderate & \\
\hline & A3 & Sheet erosion - severe & \\
\hline & A4 & Rills & \\
\hline & A5 & Gullies & \\
\hline & A6 & Ravines - shallow & \\
\hline & A7 & Ravines - deep & \\
\hline \multirow[t]{6}{*}{ Wind erosion } & B1 & Sheet erosion - slight & \\
\hline & B2 & Sheet erosion - moderate & \\
\hline & B3 & Sheet erosion - severe & \\
\hline & B4 & Stabilized dunes & \\
\hline & B5 & Partially stabilized dunes & \\
\hline & B6 & Unstabilized dunes & \\
\hline \multirow[t]{2}{*}{ Waterlogging } & $\mathrm{C} 1 / \mathrm{C} 2$ & Surface ponding - seasonal/permanent & \\
\hline & C3 & Subsurface waterlogged & \\
\hline \multirow[t]{4}{*}{ Salinization/alkalization } & D1-D3 & Saline - slight/moderate/severe & \\
\hline & D4-D6 & Sodic - slight/moderate/severe & \\
\hline & D7-D9 & Saline sodic - slight/moderate/severe & \\
\hline & D10 & Rann & \\
\hline Acidification & $\mathrm{E} 1 / \mathrm{E} 2$ & Acidic-moderate/severe & \\
\hline \multirow[t]{2}{*}{ Glacial } & F1 & Frost heaving & \\
\hline & F2 & Frost shattering & \\
\hline \multirow[t]{3}{*}{ Anthropogenic } & G1 & Industrial effluent-affected areas & \\
\hline & G2 & Mining and dump areas & \\
\hline & G3 & Brick kiln & \\
\hline \multirow[t]{3}{*}{ Others } & $\mathrm{H} 1$ & Mass movement/mass wastage & \\
\hline & $\mathrm{H} 2$ & Barren rocky/stony waste & \\
\hline & H3 & Riverine sands/sea Ingress, etc. & \\
\hline
\end{tabular}


Table 3. Category-wise distribution of LD (2015-2016) in different states of India (area in ha)

\begin{tabular}{|c|c|c|c|c|c|c|c|c|c|}
\hline State & $\begin{array}{l}\text { Water } \\
\text { erosion }\end{array}$ & $\begin{array}{l}\text { Wind } \\
\text { erosion }\end{array}$ & Waterlogging & $\begin{array}{l}\text { Salinization/ } \\
\text { alkalization }\end{array}$ & Acidification & Glacial & $\begin{array}{l}\text { Anthro- } \\
\text { pogenic }\end{array}$ & Others & Total \\
\hline Andhra Pradesh & $4,773,702$ & 15,556 & 4,399 & 365,639 & & & 59,452 & 292,008 & $5,510,756$ \\
\hline Arunachal Pradesh & 442,920 & & 35,033 & & $3,36,881$ & 585 & & 167,442 & 982,861 \\
\hline Assam & 359,168 & & 268,671 & & 73,885 & & 11,703 & 27,990 & 741,417 \\
\hline Bihar & 345,027 & & 711,112 & 113,918 & & & 4787 & 16,834 & $1,191,678$ \\
\hline Chhattisgarh & $3,236,127$ & & & & 94 & & 37,451 & 356,281 & $3,629,953$ \\
\hline Goa & 24,732 & & 769 & 1,347 & 37 & & 8823 & 7,373 & 43,081 \\
\hline Gujarat & $1,618,709$ & 1,328 & 85,339 & $3,793,377$ & & & 35,645 & 454,500 & $5,988,898$ \\
\hline Haryana & 107,110 & 131,052 & 35,260 & 95,852 & & & 9,078 & 10,869 & 389,221 \\
\hline Himachal Pradesh & 315,119 & & 41 & & & 737,847 & 1,797 & 225,037 & $1,279,841$ \\
\hline $\begin{array}{c}\text { Jammu and } \\
\text { Kashmir }\end{array}$ & 247,647 & & 1,187 & & & 100,909 & 1,135 & $1,039,725$ & $1,390,603$ \\
\hline Jharkhand & $1,196,920$ & & 354 & & & & 45,979 & 76,523 & $1,319,776$ \\
\hline Karnataka & $4,876,020$ & & 2,004 & 116,510 & 33,797 & & 62,217 & 179,657 & $5,270,205$ \\
\hline Kerala & 74,695 & & 69,037 & & 54,092 & & 5,691 & 94,021 & 297,536 \\
\hline Ladakh & 500,070 & 236,594 & & 45,602 & & $1,786,476$ & & $6,313,507$ & $8,882,248$ \\
\hline Madhya Pradesh & $5,630,509$ & & 92 & 25,601 & & & 42,598 & 210,642 & $5,909,442$ \\
\hline Maharashtra & $10,613,283$ & & & 183,433 & 1351 & & 46,212 & 148,627 & $10,992,906$ \\
\hline Manipur & 221,931 & & 1,343 & & 631,463 & & & 261 & 854,998 \\
\hline Meghalaya & 86,767 & & 304 & & 458,765 & & 7,387 & 83,264 & 636,487 \\
\hline Mizoram & 266,577 & & & & 469,594 & & & & 736,171 \\
\hline Nagaland & 35,843 & & & & 743,388 & & 888 & & 780,119 \\
\hline Odisha & $5,832,981$ & 335 & 16,091 & 3,057 & 18,835 & & 34,370 & 61,448 & $5,967,117$ \\
\hline Punjab & 62,568 & 44,311 & 11,447 & 4,252 & & & 12,614 & 23,463 & 158,655 \\
\hline Rajasthan & $2,752,487$ & $13,805,182$ & 8,769 & 536,207 & & & 91,655 & 839,766 & $18,034,066$ \\
\hline Sikkim & 5362 & & & & & 11,271 & & 59,657 & 76,290 \\
\hline Tamil Nadu & $1,766,278$ & 45,382 & 10,540 & 346,468 & 124,141 & & 28,495 & 119,237 & $2,440,541$ \\
\hline Telangana & $2,879,100$ & & 2,499 & 230,639 & 249 & & 48,855 & 72,079 & $3,233,421$ \\
\hline Tripura & 6076 & & 298 & & 94,906 & & 1,050 & 392 & 102,722 \\
\hline Uttar Pradesh & $1,695,505$ & & 444,966 & 600,630 & & & 24,300 & 92,509 & $2,857,910$ \\
\hline Uttarakhand & 621,798 & & 188 & & & 246,776 & 2,040 & 74,731 & 945,533 \\
\hline West Bengal & 341,584 & & 111,657 & 753 & & & 30,219 & 9,327 & 493,540 \\
\hline $\begin{array}{l}\text { Andaman and } \\
\text { Nicobar Islands }\end{array}$ & 47,388 & & & & & & 191 & 5,349 & 52,928 \\
\hline Chandigarh & 57 & & & & & & & & 57 \\
\hline Dadra Nagar & 5802 & & 28 & & & & & & 5,830 \\
\hline \multicolumn{10}{|l|}{ Haveli } \\
\hline Daman and Diu & 329 & & 364 & & & & 133 & 41 & 867 \\
\hline Delhi & 6098 & & & & & & 21 & 1179 & 7,298 \\
\hline Lakshadweep & & & & & & & & 42 & 42 \\
\hline Puducherry & 16 & & 3 & 1326 & & & & 303 & 1,649 \\
\hline Grand total & $50,996,301$ & $14,279,746$ & $1,821,795$ & $6,464,608$ & $3,041,478$ & $2,883,858$ & 654,791 & $11,064,073$ & $91,206,650$ \\
\hline $\begin{array}{l}\% \text { Total } \\
\quad \text { geographic area }\end{array}$ & 15.53 & 4.35 & 0.55 & 1.97 & 0.93 & 0.88 & 0.20 & 3.37 & 27.77 \\
\hline$\% \mathrm{LD}$ & 55.91 & 15.66 & 2.00 & 7.09 & 3.33 & 3.16 & 0.72 & 12.13 & 100.00 \\
\hline
\end{tabular}

(which is $27.77 \%$ of the geographical extent of India) during 2015-2016. Figure 2 shows the LD map of India for 2015-2016.

Table 3 shows the process-wise overall status of LD in India during 2015-2016.

In 2005-2006, about 91,298,198 ha of land was under various processes of LD in India, while it had reduced to 91,206,650 ha during 2015-2016, showing a marginal decrease in LD status just over a decade. The processwise extent of LD during 2015-2016, along with necessary explanation is presented in the following sections. Table 4 presents the crossmatrix of decadal changes in LD. Table 5 lists the positive and negative changes in LD extent during the ten-year period.
Spatial distribution of land degradation during 2015-2016

Water erosion was the major process causing LD in India, accounting for $55.91 \%$ of total LD or $15.53 \%$ of total geographical area (TGA) of the country. This was followed by wind erosion spread over nearly $14,279,746$ ha and accounting for $15.66 \%$ of total LD or $4.35 \%$ of TGA. The salinization/alkalization (comprising various categories like saline, sodic and saline-sodic and Rann) was spread over $6.5 \mathrm{M}$ ha, accounting for $7.09 \%$ of total LD. Acidification covered over $3.04 \mathrm{M}$ ha $(3.33 \%$ of total LD); this spatial extent excluded paddy lands, dense forests and plantations. The barren rocky, mass movement 


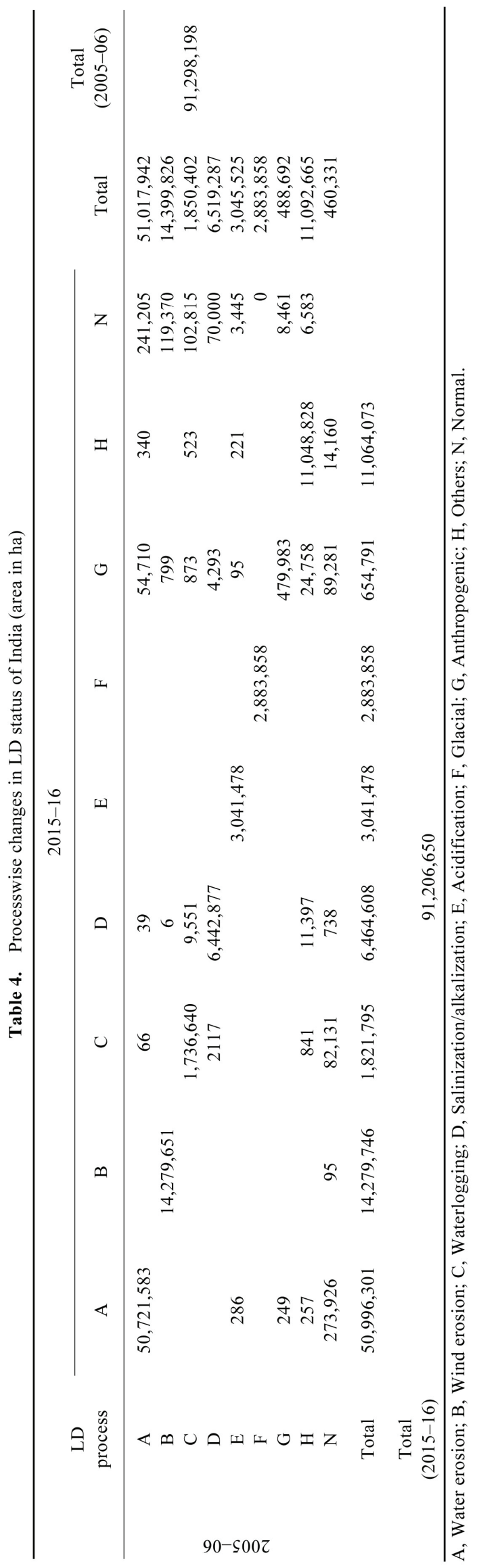


Table 5. Major positive and negative decadal changes in LD status of India

\begin{tabular}{|c|c|}
\hline Negative changes & Area (ha) \\
\hline Water erosion moderate $\rightarrow$ water erosion severe & 314,158 \\
\hline Normal $\rightarrow$ water erosion & 273,926 \\
\hline Water erosion slight $\rightarrow$ water erosion moderate/severe & 194,833 \\
\hline Normal $\rightarrow$ waterlogging & 82,131 \\
\hline Water erosion $\rightarrow$ industrial effluent-affected areas/mining/brick kiln & 54,710 \\
\hline Normal $\rightarrow$ industrial effluent-affected areas/mining/brick kiln & 63,318 \\
\hline Normal $\rightarrow$ mass movement/riverine sand & 14,160 \\
\hline Riverine sand $\rightarrow$ salinity & 11,397 \\
\hline Saline slight $\rightarrow$ saline moderate/severe & 10,481 \\
\hline Waterlogging $\rightarrow$ salinity & 9,551 \\
\hline Seasonal waterlogging $\rightarrow$ surface permanent/subsurface waterlogging & 5,643 \\
\hline Saline moderate $\rightarrow$ saline severe & 3,945 \\
\hline Normal $\rightarrow$ salinity & 738 \\
\hline Riverine sand $\rightarrow$ waterlogging & 841 \\
\hline Sodic slight $\rightarrow$ sodic moderate/severe & 824 \\
\hline Wind erosion $\rightarrow$ industrial effluent-affected areas/mining/brick kiln & 799 \\
\hline Saline sodic slight $\rightarrow$ saline sodic moderate/severe & 645 \\
\hline Water erosion $\rightarrow$ mass movement/riverine sand & 340 \\
\hline Acidity moderate $\rightarrow$ acidification severe & 1,351 \\
\hline Waterlogging $\rightarrow$ mining/brick kiln & 857 \\
\hline Positive changes & Area (ha) \\
\hline Partially stabilized/unstabilized dunes $\rightarrow$ stabilized dunes & 439,210 \\
\hline Water erosion severe $\rightarrow$ water erosion moderate & 418,631 \\
\hline Water erosion moderate/severe/rills $\rightarrow$ water erosion slight & 350,644 \\
\hline Water erosion $\rightarrow$ normal & 219,165 \\
\hline Wind erosion $\rightarrow$ normal & 119,448 \\
\hline Waterlogging $\rightarrow$ normal & 103,643 \\
\hline Salinity $\rightarrow$ normal & 69,942 \\
\hline Barren rocky $\rightarrow$ mining & 24,447 \\
\hline Saline moderate $\rightarrow$ saline slight & 19,525 \\
\hline Saline severe $\rightarrow$ saline moderate/slight & 16,914 \\
\hline Stabilized/unstabilized dunes $\rightarrow$ wind sheet erosion & 15,676 \\
\hline Industrial effluent-affected areas/mining/brick kiln $\rightarrow$ normal & 8,493 \\
\hline Mass movement/barren rocky/riverine sand $\rightarrow$ normal & 8,310 \\
\hline Surface permanent/subsurface waterlogging $\rightarrow$ seasonal waterlogging & 6,328 \\
\hline Salinity $\rightarrow$ industrial effluent-affected areas/mining/brick kiln & 4,293 \\
\hline Saline sodic severe $\rightarrow$ saline sodic moderate & 4,089 \\
\hline Acidification $\rightarrow$ normal & 3,448 \\
\hline Saline sodic moderate $\rightarrow$ saline sodic slight & 2,767 \\
\hline Sodic moderate $\rightarrow$ sodic slight & 2,226 \\
\hline Salinity $\rightarrow$ waterlogging & 2,117 \\
\hline Unstabilized dunes $\rightarrow$ partially stabilized dunes & 953 \\
\hline Waterlogging $\rightarrow$ riverine sand & 523 \\
\hline Sodic severe $\rightarrow$ sodic slight/moderate & 460 \\
\hline
\end{tabular}

and riverine sands ('others' category) accounted for $12.13 \%$ of total LD (3.37\% of TGA).

Among the states, Rajasthan had maximum LD extending over $18.03 \mathrm{M}$ ha and accounting for $19.77 \%$ of total LD of the country. The main process of LD was wind erosion in this state, followed by water erosion. Rajasthan was closely followed by Maharashtra with $10.99 \mathrm{M}$ ha land under $\mathrm{LD}$, accounting for $12.05 \%$ of total LD (Table 3). In Maharashtra, the major LD process was water erosion, followed by salinization/alkalization.

Water erosion was found to be the dominant process in majority of the states, especially in the central plateau region of India. It was highest in Maharashtra, followed by Odisha and Madhya Pradesh. High rainfall variability and intensity, undulating terrain conditions and moderate to high erodibility of soils were the major factors for extensive water erosion in these areas. Soils of Maharashtra are mainly black with high clay content. Here, farmers allow the water to flow out during rainy season to avoid water logging associated with low infiltration capacity in these soils, the main reason for soil erosion by water in such areas. In the red soil region of the southern plateau, the undulating terrain conditions and cultivation practices along the slopes are the main factors for sheet erosion 
by water $^{8}$. The decadal changes in soil erosion status indicate a marginal decrease in the spatial extent. However, substantial decrease in severity of water erosion classes was noticed, associated with better landcover conservation measures mainly through surface canopy cover.

Wind erosion occurred over $14.28 \mathrm{M}$ ha land, contributing to $15.66 \%$ of total LD in India or $4.35 \%$ of TGA. Wind erosion was predominant in the arid regions, mostly in Rajasthan (hot desert) as a dominant process, followed by Ladakh (cold desert) and Haryana. It occurred to a lesser extent in Tamil Nadu, Punjab, Andhra Pradesh, Gujarat and Odisha, in decreasing order. Sand dunes formed due to localized sand deposition were the main form of wind erosion, followed by removal of fine soil in the form of sheet erosion. Lack of natural vegetation cover due to the prevailing arid conditions and poor binding capacity of soils were the main reasons for wind erosion in these areas. The accelerated wind erosion problems in western Rajasthan due to anthropogenic interventions have been highlighted by many researchers ${ }^{9}$.

Acidification was spread over $3.04 \mathrm{M}$ ha $(3.33 \%$ of total LD), excluding paddy lands and dense forest areas as well as plantations. It was pronounced in Nagaland, Manipur, Mizoram, Meghalaya, Arunachal Pradesh, Tamil Nadu, Tripura, Assam, Kerala, Karnataka, Odisha and Maharashtra, in a decreasing order. This was mostly confined to the high-rainfall regions and mainly formed due to leaching of alkaline salts to lower depths ${ }^{10}$. In these areas, the acid soils under plantation crops and paddy fields were excluded from mapping. The areas under dense forests/plantations were excluded since acidification does not affect the yield significantly. In paddygrowing areas, $\mathrm{pH}$ of soils increases under submerged conditions $^{11}$, thereby neutralizing the ill-effects of low $\mathrm{pH}$ on crop performance.

Waterlogging was found to be highest in Bihar, followed by Uttar Pradesh and Assam. It was spread over an area of $1.82 \mathrm{M}$ ha, accounting for $2.00 \%$ of total LD in India. It was observed to a lesser extent in Himachal Pradesh, Madhya Pradesh, Uttarakhand, Tripura, Meghalaya, Jharkhand, Goa, Manipur, Jammu and Kashmir, Karnataka and Telangana, in increasing order of area. However, this LD process was not found in Chhattisgarh, Maharashtra, Mizoram, Nagaland and Sikkim. It was mainly confined to the coastal areas and lower slope elements. The reasons for waterlogging vary from area to area due to localized factors. For example, in Uttar Pradesh, waterlogging is mainly observed in the central and eastern parts where vertical movement of water is restricted due to the presence of subsurface kankar layer. While in undulating granitic terrain of NorthEast, Central and South India, water logging is confined to the lower elements of slope due to accumulation of sub-surface seepage from the adjacent upland irrigated paddy fields. The duration of water logging in these areas is seasonal.
The salinization/alkalization was spread over $6.46 \mathrm{M}$ ha, accounting for $7.09 \%$ of total LD in India. It was found extensively in Gujarat (4.2\% of total LD), followed by Uttar Pradesh (0.66\%) and Rajasthan (0.59\%). This process was significant in Andhra Pradesh, Tamil Nadu, Telangana, Maharashtra, Bihar, Karnataka, Haryana, Ladakh, Madhya Pradesh, Punjab and Odisha, in decreasing order of area. In Gujarat, it was mainly due to saline water intrusion into coastal areas from the sea. In the northern alluvial belt, the salt-affected areas were mainly saline-sodic and sodic in nature with geogenic origin from alluvium. Alkalization in the southern plateau was mainly located in the valley-fill areas, formed due to chemical weathering of plagioclase feldspar. The salinization source was mainly coastal saline water intrusion in this region. Distribution of sodic soils showed common occurrence in the arid and semi-arid regions ${ }^{12}$. Besides, states such as Rajasthan and Haryana are affected with poor-quality groundwater. Continuous use of pumped water for irrigation has contributed to the problem of salinity and sodicity ${ }^{13}$.

Glacial processes consisting of frost shattering and frost heaving covered an area of $2.88 \mathrm{M}$ ha, i.e. $3.16 \%$ of total LD or $0.88 \%$ TGA. Glacial processes, as the name suggests, occur in the cold desert areas in Jammu and Kashmir, Ladakh, Himachal Pradesh, Uttarakhand, Sikkim and Arunachal Pradesh. The dominant degradation type is frost shattering, followed by frost heaving. The frost heaving occurs in the valley regions where the subsurface is frozen, making it difficult for useful plants to grow. Most of these lands remain as pastures and cannot support any crops.

The anthropogenic processes which include industrial affluent areas, mining and dumps and brick kilns extended to an area of $6548 \mathrm{~km}^{2}$, accounting for $0.72 \%$ of total degraded land in the country. The extent of LD due to anthropogenic activities was found maximum in Karnataka, Rajasthan and Andhra Pradesh followed by Telangana. The main source of LD due to anthropogenic activities was mining, followed by brick kilns.

Other LD processes like barren rocky outcrops, mass movement and riverine sand were observed to a maximum extent in Ladakh, Jammu and Kashmir and Rajasthan, followed by Gujarat, accounting for $12.13 \%$ of total LD or $3.37 \%$ of TGA. Barren rocky areas are considered as degraded land with no further possibility of severity change. Mass movement was mainly distributed in the foothill zones of the Himalayan region.

\section{Decadal changes in land degradation status}

Area under LD in India during 2005-2006 (first cycle) was $91.30 \mathrm{M}$ ha, which reduced marginally to $91.21 \mathrm{M}$ ha during 2015-2016 (second cycle). The change analysis between the first and second cycles of LD revealed an 
Table 6. Accuracy assessment

\begin{tabular}{|c|c|c|c|c|c|}
\hline Class description & $\begin{array}{l}\text { LD class } \\
\text { code }\end{array}$ & $\begin{array}{l}\text { Producer's } \\
\text { accuracy }\end{array}$ & $\begin{array}{c}\text { User's } \\
\text { accuracy }\end{array}$ & $\begin{array}{c}\text { Producer's } \\
\text { confidence interval }\end{array}$ & $\begin{array}{l}\text { User's confidence } \\
\text { interval }\end{array}$ \\
\hline Normal areas (with no apparent land degradation) & Normal & 0.926 & 0.959 & 0.016 & 0.013 \\
\hline Water erosion: sheet erosion - slight & A1 & 0.711 & 0.794 & 0.086 & 0.081 \\
\hline Water erosion: sheet erosion - moderate & A2 & 0.781 & 0.826 & 0.060 & 0.057 \\
\hline Water erosion: sheet erosion - severe & A3 & 0.692 & 0.806 & 0.086 & 0.079 \\
\hline Water erosion: rills & A4 & 0.867 & 0.867 & 0.102 & 0.102 \\
\hline Water erosion: gullies & A5 & 0.806 & 0.833 & 0.117 & 0.112 \\
\hline Water erosion: ravines-shallow & A6 & 0.909 & 0.811 & 0.082 & 0.106 \\
\hline Water erosion: ravines - moderately deep to deep & A7 & 0.917 & 0.825 & 0.076 & 0.099 \\
\hline Wind erosion: sheet - slight & B1 & 0.750 & 0.632 & 0.126 & 0.129 \\
\hline Wind erosion: sheet - moderate & B2 & 0.886 & 0.838 & 0.088 & 0.100 \\
\hline Wind erosion: sheet - severe & B3 & 0.852 & 0.719 & 0.112 & 0.131 \\
\hline Wind erosion: stabilized dunes & B4 & 0.806 & 0.833 & 0.117 & 0.112 \\
\hline Wind erosion: Partially stabilized dunes & B5 & 0.875 & 0.800 & 0.096 & 0.111 \\
\hline Wind erosion: unstabilized dunes & B6 & 0.935 & 0.967 & 0.073 & 0.054 \\
\hline Waterlogging: surface ponding - seasonal & $\mathrm{C} 1$ & 0.781 & 0.893 & 0.120 & 0.096 \\
\hline Waterlogging: surface ponding - permanent & $\mathrm{C} 2$ & 0.871 & 0.794 & 0.099 & 0.114 \\
\hline Waterlogging - subsurface & $\mathrm{C} 3$ & 0.947 & 0.857 & 0.084 & 0.126 \\
\hline Salt-affected: saline - slight & D1 & 0.680 & 0.810 & 0.153 & 0.141 \\
\hline Salt-affected: saline - moderate & D2 & 0.871 & 0.844 & 0.099 & 0.106 \\
\hline Salt-affected: saline - severe & D3 & 0.870 & 0.833 & 0.116 & 0.125 \\
\hline Salt-affected: sodic - slight & D4 & 0.875 & 0.840 & 0.111 & 0.121 \\
\hline Salt-affected: sodic - moderate & D5 & 0.897 & 0.765 & 0.093 & 0.120 \\
\hline Salt-affected: sodic - severe & D6 & 0.950 & 0.760 & 0.080 & 0.141 \\
\hline Salt-affected: saline sodic - slight & D7 & 0.778 & 0.875 & 0.132 & 0.111 \\
\hline Salt-affected: saline sodic - moderate & D8 & 0.964 & 0.900 & 0.058 & 0.090 \\
\hline Salt-affected: saline sodic - severe & D9 & 0.926 & 0.893 & 0.083 & 0.096 \\
\hline Rann & D10 & 0.919 & 0.895 & 0.074 & 0.082 \\
\hline Acidity - moderate & E1 & 0.783 & 0.857 & 0.141 & 0.126 \\
\hline Acidity - severe & E2 & 0.913 & 0.724 & 0.097 & 0.137 \\
\hline Frost heaving & $\mathrm{F} 1$ & 0.966 & 0.875 & 0.056 & 0.096 \\
\hline Frost shattering & $\mathrm{F} 2$ & 0.964 & 0.794 & 0.058 & 0.114 \\
\hline Industrial effluent-affected areas & G1 & 0.923 & 0.828 & 0.086 & 0.115 \\
\hline Mining and dump areas & $\mathrm{G} 2$ & 0.960 & 0.828 & 0.064 & 0.115 \\
\hline Brick kiln areas & G3 & 0.938 & 0.909 & 0.070 & 0.082 \\
\hline Mass movement/mass wastage & $\mathrm{H} 1$ & 0.923 & 0.828 & 0.086 & 0.115 \\
\hline Barren rocky/stony waste & $\mathrm{H} 2$ & 0.730 & 0.871 & 0.120 & 0.099 \\
\hline Miscellaneous - riverine sands/sea ingress areas & $\mathrm{H} 3$ & 0.821 & 0.821 & 0.119 & 0.119 \\
\hline
\end{tabular}

overall decrease to a tune of $915 \mathrm{~km}^{2}(0.03 \%$ of TGA of the country) during a ten-year time span.

Various efforts of land reclamation and soil conservation measures have resulted in the conversion of $0.55 \mathrm{M}$ ha of LD area to normal category (no apparent LD) during these 10 years (Table 5). The conversion of LD areas to normal category was observed in water erosion ( $0.24 \mathrm{M} \mathrm{ha})$ followed by wind erosion $(0.12 \mathrm{M} \mathrm{ha})$, waterlogging $(0.10 \mathrm{M} \mathrm{ha})$ and salinity $(0.07 \mathrm{M} \mathrm{ha})$ areas. Majority of such changes were found in Rajasthan, Odisha, Haryana, Gujarat, Maharashtra and Madhya Pradesh.

A sizable increase in LD was observed in Mizoram, Assam, Arunachal Pradesh, Bihar, Manipur, Nagaland and Meghalaya, mainly due to landslides and shifting cultivation. The changes were not only from normal class to other LD classes or vice versa, but also within the classes of the same LD process/between different LD processes. Table 5 presents the decadal changes in LD processes. It is obvious that the anthropogenic-related degradation was the main cause for increase in LD during the study period. It can also be noted that a sizable area was brought to normal use mainly through soil conservation programmes as well as salt-affected soil reclamation programmes adopted under specific missions, and under the watershed development programmes of the Union and State Governments.

During the ten-year period of analysis, an area of $0.46 \mathrm{M}$ ha of normal land was observed to have degraded. Among the main processes, water erosion contributed maximum $(0.27 \mathrm{M}$ ha), followed by anthropogenic activities $(0.09 \mathrm{M}$ ha) and waterlogging (0.08 M ha). Such changes were found in Mizoram, Odisha, Assam, Bihar and Arunachal Pradesh.

Table 5 also provides category-wise decadal changes in LD. These include both positive and negative changes and are arranged in decreasing order of areal extent. The main 
improvement in LD status was stabilization of sand dunes. During this period, nearly $0.22 \mathrm{M}$ ha of land was restored to normal from water erosion. The changes from waterlogged areas to normal (nearly $0.1 \mathrm{M}$ ha) could be achieved through improved drainage conditions and also due to less rainfall during 2015-2016.

In Rajasthan, Jharkhand, Punjab and Odisha, the normal category (no apparent LD) was converted to degraded land by anthropogenic activities. Areas under waterlogging during 2005-2006 in Haryana, Kerala, Gujarat, Assam and Punjab have been changed to normal category, while in Bihar, Assam, Haryana and West Bengal normal lands became waterlogged in 2015-2016.

It was observed that majority of area under water erosion was being converted to mining and brick kilns. These changes to brick kilns were noticed in alluvial plains, while mining was noticed in the Deccan Plateau region. Waterlogged areas were converted to saline patches in parts of Haryana, Uttar Pradesh, Gujarat and Punjab. The areas covered by sand dunes were changed to normal category in parts of Rajasthan and Haryana with the introduction of irrigation facilities.

Positive changes observed were from partially stabilized and unstabilized dunes to stabilized dunes $(0.44 \mathrm{M} \mathrm{ha})$, followed by water erosion-sheet erosion-severe/rills to water erosion-moderate $(0.41 \mathrm{M} \mathrm{ha})$ and water erosion to normal (0.22 M ha). Discernible negative changes occurred in the category of severe water erosion $(0.78 \mathrm{M}$ ha). This has resulted mainly due to improper agriculture practices followed in the tribal areas.

\section{Accuracy assessment}

Accuracy assessment was carried out to quantify the reliability of the LD map. Table 6 presents the accuracy estimation. Result shows an overall accuracy of $87.2 \%$, with a kappa coefficient of 0.851 . The producer's accuracy varied between 0.632 and 0.967 , while the user's accuracy varied between 0.680 and 0.966 .

Among all the classes, the 'slight' category of water as well as wind erosion showed relatively poor accuracy owing to the uncertainty associated with demarcation from normal lands due spectral similarity. Use of slope information from the DEM has improved its delineation to a great extent. Use of high spatial resolution datasets helped in improving the delineation associated with land conservation information, such as field bunds. The ravines have relatively clear signature, making it possible to delineate them with better accuracy (more than 0.9). Accuracy of gullied land (A4) delineation was mainly influenced by interference from scrub land. Due to usage of short wave infrared (SWIR) band, delineation of waterlogged areas could be improved substantially. Owing to the spectral contrast from normal background and knowledge obtained from historical salt-affected soil maps, salt-affected lands have been delineated with much better accuracy. The usage of location-terrain association and lithology of the area has helped in sub-categorizing these into saline, sodic and saline-sodic soils. Better accuracy of brick-kiln delineation was possible using high-resolution data and local knowledge available with partner institutions.

Among all these classes, the land with no apparent degradation (normal category) had the lowest confidence interval (CI) for both producer's and user's accuracy of 0.013. The highest CI was for the salt-affected-sodicsevere (D6) class with respect to producer's accuracy, while it was for the salt-affected-saline-slight (D1) class with respect to user's accuracy.

\section{Conclusion}

Resourcesat-based LISS-III sensors data were used for the assessment of LD characterization at district level. The existing geospatial database on LD should be useful for understanding vulnerability of soil resources for degradation, decadal changes in LD in the country, and prioritizing areas for land reclamation programmes. It should also serve as an important input to address the various components of LD neutrality to which India is committed in the recent COP-14 of UNCCD. For fieldscale implementation planning of land reclamation programmes, use of very high spatial resolution data from sensors like Cartosat-2E is envisaged. Efforts are also being made to develop object classification based methodology for mapping large-scale LD status.

1. Bhattacharyya, R., Ghosh, B. N., Mishra, P. K., Mandal, B., Rao, C. S., Sarkar, D. and Franzluebbers, A. J., Soil degradation in India: challenges and potential solutions. Sustainability, 2015, 7(4), 3528-3570; https://doi.org/10.3390/su7043528.

2. Navalgund, R. R., Indian Earth Observation Programme toward societal benefits: a GEOSS perspective. In GEOSS and NextGeneration Sensors and Missions, International Society for Optics and Photonics, 2006, vol. 6407, p. 640701; http://repository. ias.ac.in/89366/1/45P.pdf

3. NRSC, Nationwide mapping of Land degradation using multitemporal satellite data. Project Manual. Soil and Land Resources Assessment Division, Earth Resources Group, RS \& GIS application area, Department of Space, Govt of India, Balanagar, Hyderabad, 2007.

4. Sujatha, G., Mitran, T., Tummala, K., Suresh, K. G. J. R., Fyzee, M. A., Sreenivas, K. and Ravisankar, T., A decision based approach to develop action plans for land degradation neutrality using geospatial techniques in a semi-arid region of India. J. Geomatics, 2019, 13(2), 188-194.

5. Manchanda, M. L., Kudrat, M. and Tiwari, A. K., Soil survey and mapping using remote sensing. Tropical Ecol., 2002, 43(1), 61-74.

6. Congalton, R., A Review of assessing the accuracy of classifications of remotely sensed data. Remote Sens. Environ., 1991, 37, 35-46; https://doi.org/10.1016/0034-4257(91)90048-B.

7. Snedecor, G. W. and Cochran, W. G., Statistical methods 6th edition. The Iowa State University, 1967. 
8. Zhang, Z., Sheng, L., Yang, J., Chen, X. A., Kong, L. and Wagan, B., Effects of land use and slope gradient on soil erosion in a red soil hilly watershed of southern China. Sustainability, 2015, 7(10), 14309-14325; https://doi.org/10.3390/su71014309

9. Singh, S., Kar, A., Joshi, D. C., Kumar, S. and Sharma, K. D., Desertification problem in western Rajasthan. Annals Arid Zone, 1994, 33, 191-191.

10. Maji, A. K., Obi Reddy, G. P. and Sarkar, D., Acid soils of India their extent and spatial distribution. NBSS Publication, 2012; http://krishi.icar.gov.in/jspui/handle/123456789/22308

11. Matsuo, K., Ae, N., Vorachit, S. and Thadavon, S., Present soil chemical status and constraints for rice-based cropping systems in Vientiane plain and neighboring areas, Lao PDR. Plant Production Sci., 2015, 18(3), 314-322; 10.1626/pps.18.314.

12. Mandal, A. K., Sharma, R. C. and Singh, G., Assessment of salt affected soils in India using GIS. Geocarto Int., 2009, 24(6), 437456; https://doi.org/10.1080/10106040902781002

13. Bhalla, A., Singh, G., Kumar, S., Shahi, J. S. and Mehta, D., Elemental analysis of ground water from different regions of Punjab state (India) using EDXRF technique and the sources of water contamination. In Int. Conf. Environ. Computer Sci., 2011, vol. 19, pp. 156-164; http://ipcbee.com/vol19/31-ICECS2011R20009.pdf

14. NRSC, Status of Land degradation in India: 2015-16 (ATLAS). National Remote Sensing Centre, ISRO, Govt of India, Hyderabad, 2019

15. NBSS and LUP, National Bureau of Soil Survey and Land Use Planning. Annual Report, NBSS\&LUP, Nagpur, 2005.

16. NBSS and LUP, Global Assessment of Soil Degradation (GLASOD) Guidelines. National Bureau of Soil Survey and Land Use Planning, Nagpur, 1994.

17. MoA, Indian Agriculture in Brief. 25th edn; Directorate of Economics and Statistics, Ministry of Agriculture, Department of Agriculture and Cooperation, Government of India, New Delhi, 1994.
18. NRSA, Waste Land Atlas of India. National Remote Sensing Centre, Government of India, Balanagar, Hyderabad, 2000.

19. NWDB, Guidelines for Action. National Wasteland Development Board. Ministry of Environment and Forests, Government of India, New Delhi, 1985.

20. Bhumbla, D. R. and Khare, A., Estimates of wastelands in India. Society for Promotion of Wastelands Development (SPWD), New Delhi, 1984.

21. Vohra, B. B., A Policy for Land and Water; Department of Environment, Government of India, New Delhi, 1980, vol. 18, pp. 6470 .

22. MoA, Indian Agriculture in Brief. 20th edn; Directorate of Economics and Statistics, Ministry of Agriculture, Department of Agriculture and Cooperation, Ministry of Agriculture, Government of India, New Delhi, 1978.

23. NCA, Report of the National Commission on Agriculture. National Commission of Agriculture, Government of India, New Delhi, India, 1976, pp. 427-472; https://indianculture.gov.in/nationalcommission-agriculture-1976

ACKNOWLEDGEMENTS. We thank the Indian Space Research Organisation (ISRO) for funding this project, and Shantanu Choudhary (Director, NRSC, ISRO) for support during the execution of this project. We also thank our partner institutions and those who have contributed directly or indirectly to this, and Vijay Solanki and Ms Sahana Hegde, Senior Research Fellows, NRSC, for their valuable contribution.

Received 17 February 2021; revised accepted 21 May 2021

doi: $10.18520 / \mathrm{cs} / \mathrm{v} 121 / \mathrm{i} 4 / 539-550$ 